\title{
Empowerment of Women through Self Help Group in Madhya Pradesh: A Sociological Study
}

\author{
Mukhtar Ahmad Bhat \& Irshad Ahmad Wani, Ahsan Ahrar, Manzoor Ahmad
}

\begin{abstract}
Women in India represent a more traditional section of society and have been reflected throughout the ages. Therefore, their participation in any walk of life is viewed as a sign of progress, particularly in the case of economic field. This paper is an attempt to know, what is the impact of micro-finance on, women's empowerment in Madhya Pradesh. Micro finance institution started in India in 1980s through self help groups (SHGs) model. It is the Grameen replication model of Bangladesh. Women empowerment through SHG (Self Help Group) based micro finance has been central to development agenda in India. Self help group projects were launched by Government of India, with the financial assistance from IFAD \& empower rural poor women through micro finance. The present study is an attempt in this direction to analyze the impact of SHG projects on poor women in Sehore district of Madhya Pradesh.

Keywords: Empowerment of Women, Self Help Group (SHG), Micro finance, Development, IFAD (International Fund for Agricultural Development).
\end{abstract}

\section{Introduction:}

Women empowerment is the buzz word now-a-days. No country can afford development without considering women, who constitute nearly half of the human capital in the country. Women are an integral part of every economy. All round development and harmonious growth of a nation would be possible only when women are considered as equal partners in progress with men. They are still most deprived and neglected section of the society despite the constitutional guarantee for equal rights \& privileges for men $\&$ women. Women continue to be victims of a process of economic social, cultural \& political marginalization. So the concept of empowerment as a goal of development projects \& programs has been gaining wider acceptance.

Empowerment can serve as a powerful instrument for women to achieve upward social \& economic mobility as well as power \& status in society. It is a source of mobility, equality, both at the individual level and at the societal level. Gender development constitutes an important part of development in this content.

The concept of empowerment is defined as the process by which women take control and ownership of their choices. The core elements of empowerment have been defined as agency (the ability to define one's goals and act upon them), awareness of gendered power structures, self esteem, and self confidence (kabeer, 2001). Empowerment can take place at a hierarchy of different levels - individual, household, community and societal and is facilitated by providing encouraging factors (e.g. Exposure to new activities, which can build capacities) and removing inhibiting factors (e.g. lack of resources \& skills). In this connection micro - finance with self help groups play an effective role for promoting women empowerment. It is not only an efficient tool to fight against poverty, but also as a means of promoting the empowerment of the most marginalized sections of the population especially women.

\section{The Self Help Groups}

Self help groups are important components of micro- credit. To meet women's expressed need for improved access to credit, particularly to small loans which allow them to engage in risk averse, multi-production strategies and thereby to improve the livelihoods to their families, micro credit or self help groups have been promoted, both by the government as well as NGO's and other donors. These groups initially draw on their own accumulated savings to provide loans to their members, \& later like with the formal credit system to access funds, overcoming the limitations of their own resources. 
A self help group consists of $10-20$ members drawn form a relatively homogeneous economic class (i.e. poor) self selected on the basis existing affinities and mutual trust; members meet regularly at a fixed time and place and pool their savings into a common fund from which they take need based loans. The group develops its own rules and regulations \& sanctions for violations; the meeting procedures and processes, leadership change norms, intensive training and handholding, are designed to enable self help groups (SHG's) to function in a participatory and democratic manner. The objectives of the SHG's go beyond thrift \& Credit include the overall development of members in the social, political, cultural and economic arena; thus the SHG's are 'credit plus' institutions (Fernandez, 1998). SHG in this study is defined as a group of members voluntarily come together to form a group under NGO project with an objective of empowering economically and socially, contribute savings and thrift, invest the savings in productive enterprises or lend the saving among the group members to more to better stand of bring sustain the habit of savings in future.

Self help groups are now being viewed as dependable vehicles for rural credit delivery. SHG's have number of advantages over the traditional banking system. In the traditional banking system, there has been a strong focus on issues like economical feasibility and loan size, collateral and guarantees, productiveness of a loan, structured loans, unit costs, scheduled assets, strict schedule for recovery, recovery rates etc. The transaction costs are also high due to (a) inflexible handing terms not geared to the customer's needs. (b) poor monitoring due to absence of marketing information (c) high default rate due to political interventions (d) high documentation costs for borrowers \& (e) lack of market orientation \& proper treatment (Karmakar 1999). This system does not cater to specific dynamics of the credit needs by the poor.

The self help group offer a unique opportunity for dispensing cheap credit at the doorstep of the poor with almost assured repayments at the terms and requirements of the poor. The SHGs follow collective decision making on issue like meetings, thrift and credit decision. The participative nature of the group makes it a responsible borrower. However, the most critical factor, which stands out, is the fact that lending through SHGs focuses exclusively on the poor, who have been circumvented by the formal system. They initiate an empowerment process amongst the poor, especially the women.

After initial hesitation, the formal financial sector is now opening up to financing SHGs with their own operation. Linking self help groups with banks has been shown to be cost effective, transparent, \& flexible approach to improve the accessibility of credit from the formal banking system to the unreached rural poor. The provision of credit through SHGs reduces the direct transaction costs of the banks by $40-60 \%$ as a major task of an appraisal, supervision \& recovery of loan is taken care of by the group itself.

With over 7.8 million poor households accessing banking services including through their 458 thousand SHGs, the SHG-bank linkage programme of NABARD is now perhaps the largest micro-finance programme of the world in terms of its outreach. Over 2,000 NGOs \& 17,000 branches of 444 banks are associated with the programme. Besides being vehicles for delivery of micro-credit, self help groups can also be used to foster solidarity and collectivism among the rural poor, particularly the women. The SHGs can be tools to bring about holistic empowerment of the poor rural women. However, solidarity may be an expensive input for financial services production, as the costs of group formation and interaction may over weigh the benefits of high repayment with group control micro credit has been advocated as the new panacea for reduction of poverty. Its potential for economic empowerment of women has also been variously looked at. It has undoubtedly emerged as one of the entry points in engaging self help groups of poor women is a dialogical relationship.

\section{Review of Literature:}

Micro finance, SHG and women Empowerment is a subject that has received growing research attention in recent years. Several organizations have promoted SHGs taking up the philosophy and approach of successful experiments of extending credit to poor women. Since the early 1980 s, a large number of studies have been undertaken so far by social scientists, financial institutions and agencies, which highlight the strengths and weaknesses of SHGs, positive trends and impact of self help groups on empowerment, credit accessibility and social change examined the various dimensions of micro finance 
programmes and women empowerment. Several international organizations like Action Aid UK, CGAP (Consultative Group to Assist the poorest), and overseas development Authority have conducted case studies and organized workshops in various countries. The workshops had looked mainly into the experiences of different countries and the impact of the micro finance programmes in a cross-cultural perspective. Other sources of information include published and unpublished materials including materials from the Micro-credit Summit (February 1997 and 2001).

Over the years, "the informal sector debate" (Hart, 1973; ILO, 1972) has increased in scope and complexity. Terms such as informality were used interchangeably with informal activity, sector or economy, self employment and micro enterprise. The popularity of the informal sector concept among policy advisors and governments arose from a convergence of interest in poverty issues and the need for a policy instrument (Tokman, 1987). Governments, international financial institutions and private foundations found in the concept a common language to co-ordinate their activities and, in the case of governments, to improve their access to international welfare funds earmarked for income-generating activities. In part, the popularity of the informal sector concept comes from its ability to bridge diverse analytical and policy approaches, while its drawback is the inability to integrate approaches or improve analytical usefulness (peattie 1987).

Though many approaches and perspectives have dominated since 1984, but here the focus is only on the micro-enterprise development approach. Though new to the informal sector debate, micro enterprise promotion has evolved from poverty alleviation activities from the early 1960's. The proponents of the micro-enterprise development approach are action-oriented, not interested in conceptual issues, and are only marginally concerned with theories of the origin of micro enterprises. They accept notions of stratification, exploitation and privileged sectors of society and expand jobs and improve productivity and income. They aim to empower groups and communities through business assistance and development of organizational skills and capacity. They promote, fund, \& carry out programmes that address the needs of the poor (Rakowski, 1994).

Many micro-enterprises began as charitable and disaster relief organizations operating in rural and urban areas, while others were founded specifically to bring multinational corporate funds to the aid of the poor. Local groups often had financial support from and strong ties to international groups, especially during the first five years of operations. Charitable and welfare organizations started with short term goals, but work turned out to be never-ending. As a result many found their organizational structure "institutionalizing \& their staff "professionalizing." From direct assistance and welfare, they were transformed ever time into organizations, which focused on "helping the poor help themselves." By the early 1970s, their work concentrated on working with neighborhood or village groups on self help initiatives and grassroots economic projects (Koten, 1987).

For these NGOs the shift from charitable work and services to income generating activities was a natural outgrowth of their collective and cumulative experience in helping organize community groups. Additionally, the expansion of the informal sector, especially in the poor neighborhoods where NGO activities concentrated, led to an awareness of this sector of people in regulated, unlicensed, low resource, "marginal" activities which were critical to the survival of the poor, especially women (who predominated as heads of poor households) (Other, 1990). The 1970's marked the promotion of empowerment and social welfare through economic growth.

The NGOs of the late 1980 s and early 1990s have been expanding their role. Despite the time and resources, which NGOs as a group have invested in the poor, a tremendous amount of need remains unmet? NGOs have begun to assume a role of catalyst for micro and macro level polices and they engage in dialogues with governments and the private sector. In fact, private sector business leaders, foundations, and corporations has created new local-level NGOs for promoting micro-enterprise development through "massification" applying the NGO method and philosophy on a broader scale to help increasing number of entrepreneurs and poor families (Bejar and Korten, 1987). Massification\& overcoming institutional obstacles demand government and private sector collaboration. In direct contradiction with the legalists, NGOs stress that the most important role for government is to provide the appropriate policy environment for micro - enterprise development (Ostero, 1990). 
A large number of studies have been undertaken so far by CGAP, NGOs and donors of micro-finance programmes highlighting the strengths and weaknesses of the programme in various countries. Few studies conducted on SHGs and women Empowerment in India which have a direct relevance to the present study are presented below.

It is very difficult to review all the relevant studies since proper documentation of such studies is still to be ensured. Therefore, few studies conducted on SHGs \& women Empowerment in India which have a direct relevance to the present study as presented belong.

\section{Micro Finance and Women Empowerment: The Positive Picture:}

Some evaluations paint a positive picture of the impact of credit programs on women's lives (kabeer 2001). Access to savings and credit can initiate or strengthen series of interlinked \& mutually reinforcing 'virtuous spirals' of empowerment (Mayoux, 2000). The first set of assessments point out that women can use savings and credit for economic activity, thus increasing incomes and assets and control over their incomes and assets (Mayoux, 2000).

Rahman (1986) established that "active" women loanees had higher consumption standards and a role in household decision - making, either on their own or jointly with their husbands, than 'passive' female loanees. Both in turn had significantly higher consumption standards and were more likely to take part in household decision-making than women from male loanee households or from households who had not received credit. Similarly, Self help groups through micro credit have an important role in lessening the vulnerability of poor by creating assets, income and consumption smoothing, providing emergency assistance, and empowering and making women confident by giving them control over assets and increased self-esteem and knowledge.

During the South East Asian economic crisis, self help groups proved to be important cushions and safety nets; a high proportion of the funds made available for self help micro credit schemes were utilized by women, facilitating them to meet the subsistence requirements of their families during those hard economic times (ESCAP 2002).

Another group of evaluations have tried to establish that economic contribution may increase their role in economic decision making in the household, leading to greater well being for women and children as well as men (Mayoux, 2000).

A study by "Pitt and Khandker" (1995) in exploring the impact of female membership of credit programs found that women's preferences carried greater weight in decision making out comes including the value of women's no land assets, the total hours worked per month for cash income by men and women with in the household; fertility levels, the education of children as well as total consumption expenditure. It has also been studied that women's increased economic role may lead to change in gender roles and increased status within households \& communities (Mayoux, 2000).

The IFAD gender mainstreaming review has reported gains in self confidence and self-esteem amongst the women, enhanced capacity to articulate their needs and an increased respect in the household (IFAD, 2002).

(Yunus 2002) shows there can be a synergistic convergence of inputs (micro insurance, health services, non formal education and inputs on nutrition) in "micro-credit plus" programs. A few attempts to link micro-credit with HIV/Aids programmes have been reasonably successful (UNDP 1999). The newly set up pension fund of the Grammen Bank II is apparently quite successful.

As Mayoux (2000) puts it, these virtuous spirals are potentially mutually reinforcing in that both improved well being and change in women's position may further increase their ability to increase incomes and so on. This process if empowerment may be further reinforced by group formation focusing in savings and credit delivery as women can access wider information and support networks for economic activity; groups can support women in disputes within the household and community and groups can link to wider movements for change in women's position may further increase their ability to increase incomes and so on.

Bhatia and Bhatia (2000) through few case studies highlighted that recovery of SHG's is higher than other credit extended to borrowers. Moreover, involvement of 
SHG's had helped the bank branches in recovery of old dues. They observed that there have been perceptible changes in the living standards of the SHG members, in terms of ownership of assets, increase in savings and borrowing capacity, income generating activities and income levels as well.

Gurumoorthy (2000) maintained that SHG (self help group) is a viable alternative to achieve the objectives of rural development and to get community participation in all rural development programs. SHG is a viable organizational set up to disburse micro credit to the rural women for the purpose of making them entrepreneur and encouraging them to enter into entrepreneurial activities. Credit needs of the rural women can be fulfilled wholesomely through the SHG's. The women led SHG's have successfully demonstrated how to mobilize and manage thrift, appraise credit needs, maintain linkages with the banks and enforce financial self discipline. SHG's enhance the equality of status of women as participants, decision-makers and beneficiaries in the democratic, economic and social and cultural spheres of life. They encourage women to take active part in the socio-economic progress of the society.

V. M. Rao (2002) maintain that a review of the genesis and development of SHG's in India reveals that the existing formal financial institutions have failed to provide finances to landless, \& disadvantage groups. The origin of SHG's could be treated to mutual aid in Indian village community. SHG's encourage savings \& promote income generating activities through small loans. The experience available in the country and elsewhere suggests that SHG's are sustainable to stimulate savings, and in the process help borrower to come out of vicious circle of poverty.

Puhazhendhi, and Satyasai (2001), in their paper attempted to evaluate the performance of self help groups with special reference to social and empowerment performance of SHG's with special reference to social and economic empowerment. Primary data collected with the help of structured questionnaire from 560 sample households in 223 SHG's functioning in 11 states representing four different regions across the country formed the basis of the study. The findings of the study revealed that the SHG's as institutional arrangement could positively contribute to the economic and social empowerment of rural poor \& the impact on the later was more pronounced than on the former. Though there was no specific pattern in the performance of SHG's among different regions, the southern region could edge out other regions. The SHG's programme has been found more popular in the southern region and its progress in other regions is quite low, thus signifying an uneven achievement among the regions. Older groups had relatively more positive features like better performance than younger groups.

NailaKabir (2005) in her study on micro finance has assessed the impact of micro finance on women's empowerment. The findings suggest that there is need for caution in talking about the impact of micro finance in general. Micro-finance offers an important and effective means to achieving change on a number of different fronts, economic, social and political. The success of micro finance organizations in build up the organizational capacity of poor women provides the basis for their social mobilization that may other development interventions have been able to achieve.

Choudhary (1996) in her study stressed the need for shop sharpening women's empowering strategies to make them effective and result oriented. She pointed out that money earned by poor women is more likely to be spent on the basic needs of life than that by men \& that this realization would bring women as the focus of development efforts. She also examined the advantages of organizing women groups thereby creating a new sense of dignity \& confidence to tackle their problems with sense if solidarity and to work together for the cause of economic independence.

The preceding review shows that the strategy of micro financing through SHG's can help in a big way in eradicating poverty and empowering women. However, what is needed is a real change in the community's attitude to depart from the traditional approach of highly subsidized support for the promotion of self help. This is a time consuming process, but regular follow up and guidance are sure to bring about substantial improvement.

\section{Relevance of the study:}

Women form a crucial part of human resource. Unless this selection of population is given opportunities to prove their capabilities, the development would be imperfect. 
Women form a vital part of the Indian economy, which constitute $1 / 3^{\text {rd }}$ of the labour force and primary members contributing in the survival of the family. Women are the backbone of the agriculture sector, comprising the majority of agriculture labourers in India. In order to alleviate rural poverty, easy access to micro credit for development and promotion of micro enterprises and income generation activities is imperative. Keeping in view, SHG based micro financing programmes and projects have implemented in India. Government of India has also implemented rural women's development project known as Swashakti, which envisage SHG based micro financing for empowerment of rural poor women.

The socio-economic development of rural poor has been one of the top priorities of government both at centre level and at state level. The prevailing social and economic situations of rural areas so for prevented rural women to participate in the process of socio-economic development, Illiteracy social evils have been main barriers for rural women empowerment and their active participation in decision making and in the process of development. Various poverty alleviation schemes could not give the expected results mainly because these programmes and schemes could not accord required attention towards rural women. Keeping in view, government of India has accorded special attention towards rural women empowerment and opening up the path for their easy accessibility to various resources particularly institution credit through promotion of self help groups.

The rural women's development project jointly supported by World Bank and IFAD known as 'swashakti' project and which is one of the major projects which emphasis on formation of women SHGs and their strengthening. It was started on $16^{\text {th }}$ October 1998 for duration of 5 years. The project aims at enhancing women's access to resources for better quality of life through use of drudgery, health, literacy and imparting skills for confidence enhancement and increasing the women's control over income through involvement in skills development and income generating activities.

Though this project was implemented by central and various state governments, the performance and functioning of these projects is being affected by several socio cultural and administrative factors. Thus, the project was well planned and implemented, while impact assessment of the project is lacking to understand the dynamics of social change and empowerment of the rural women for evolving out suitable strategies to enhance the process of socio - economic empowerment is poor women.

In this context, the present study attempts to determine whether and to what extent these 'swashakti' projects have an impact on the overall empowerment of rural women in the sehore district of Madhya Pradesh. The great importance being given to the groups approach while conceptualizing and implementing any programme for the rural poor, especially women, this study becomes both essential and relevant.

\section{Methodology:}

Present study is exploratory in nature. Besides collection and analysis of primary date, secondary date and pertinent literature have been compiled and reviewed accordingly

\section{Hypothesis:}

- Poor women are capable of thrift \& swings

- Among the real and potential clients of micro finance, women are seen as the most reliable in terms of repayment and utilization of loans.

- Participation of poor women in self help groups decreases their dependency on other sources of credit.

- Poor women spend more of their income on their families.

- Micro finance empowers women since it instills a perception of strength and confidence when the poverty trap is broken.

- The process of group dynamics strengthens the networking, homogeneity and self esteem of women.

- Larger economic contribution of women enhances their status in the household and gives them greater role in decision making.

- Women are still expected to conform to gender norms even if they are also pursuing non traditional roles.

- SHGs have direct bearing on socio-economic empowerment of the rural women. 


\section{Universe of the study}

The aggregate of SHG members in sehore and Nasrullaganj blocks of sehore district of Madhya Pradesh constitute the universe of the study for which interference are to be drawn on the basis of a sample selected, so as to represent the whole population.

\section{Sampling Spectrum}

Simple random sampling procedure was adopted for this study. To validate the proposed sample two blocks of sehore districts namely sehore and Nasrullahganj blocks were selected. Sehore and Nasrullahganj blocks have a total of 180 SHG's functioning projects.

In conformity with these principles it was decided to confirm the study on the sample of $6 \%$ of the total SHGs. Accordingly out of 180 SHGs, 10 SHGs were selected randomly and out of these 10 SHGs 100 women members (10 members from each SHG) were selected randomly as respondents. In addition focus group discussions were held with the NGO facilitator's wherever possible, applicable and necessary. This was done to validate the information received from the primary and secondary data sources.

Though the SHG activity help the economic empowerment of women, the change in their familial and social status and sense of organizational bonding, the awakening of the self confidence and self respect, social and political awareness is a slow process and to achieve it, a member should have sufficient experience, of well established and well run SHGs. Hence the research was confined to cover the SHGs of Sehore\&Nasrullahganj blocks which were Nine years old.

\section{Tools and Techniques of Data Collection}

Structured interview schedule: - Interview was the principle method of primary data collection. The interviews were conducted at the place of work, at the residence of the respondents and for some of the venue of SHG meetings. The structured interview schedule consists of three parts.

The first part of the interview schedule contained questions about the socioeconomic background of the respondents. The second part consisted of questions concerning the structure and functioning of SHGs. In the third part questions are framed to known about the impact of 'swashakti' project on empowerment (Social, economic \& political) of the respondents. The wordings of some questions in interview schedule were changed in order to make them understandable to the respondents. Apart from the interview schedule, field observations and informal conversations with the respondents have also contributed to the enrichment of the primary data.

- In depth discussion: In depth discussion technique was used to generate data from district offices \& state offices.

- Focus group discussion: FGD's were also conducted with NGO facilitators for getting insights into the matter of concerns.

- In meeting observations: these observations were meant to record the moderation skills of SHG leaders and members in a live meeting situation. However, these were subject to the scheduling of SHG meetings during the fieldwork period.

\section{Presentation, Analysis \& Interpretation of the Data:}

After completion of the field investigation the filled in interview schedules were thoroughly checked, edited and processed for analysis. The data were then classified and tabulated. Simple \& crossed table's showings frequency \& percentage have been prepared.

The study is descriptive cum exploratory in nature. Data collected through primary and secondary sources were analyzed by using both qualitative \& quantitative techniques. On the basis of analysis and interpretation of data findings and broader generalization of the study have been arrived at.

The study highlights the functioning \& performance of SHG projects in Sehore district of M.P. Through these projects has led a wider socio-economic Impact on rural women. 


\section{Results and Discussions :}

Sehore is $39 \mathrm{Km}$ away from the state capital Bhopal towards south and on BhopalIndore highway. Its height from the sea level is $1500 \mathrm{ft}$. to $2000 \mathrm{ft}$. It is also connected to western railway from Bhopal to Ratlam. District area is $6578 \mathrm{Km}$. Sehore is surrounded by seven districts i.e. Bhopal, Raisen, Hoshangabad, Dewas, Shajapur, Raigarh and Harda. Sehore district extends between the parallels of latitude $22^{\circ} 31^{\prime}$ to $23^{\circ} 40^{\prime}$ north between the meridians of longitude $76^{\circ} 22^{\prime} \& 78^{\circ} 08^{\prime}$ East.

Sehore stands in the foothills of vindhyachal range in the middle of Malwa region. Sehore has a long and glorious past. ShivaShakta, Jain, Vishnu, Buddhists and Nath priests made Sehore a significant seat of their deep meditation. Sehore was a part of Bhopal estate. After formation of Madhya Pradesh the state capital Bhopal was a part of the sehore district. It was bifurcated in 1972 and a new district Bhopal was formed.

"Sidhapur" is the old name of Sehore. According to a rock-edict found from the river seevan, it got its name from 'Sidrapur'. According to an old document sehore has got its name the Anglo-Indian perversion of "Sher" or lion as pronounced by the Britisher's, since lion or 'Shers' were in the great numbers in the nearby Jungles.

Sehore has been an integral part of Awanti. Later on it was under the tulelage of Magadh dynasty, Chandragupta $1^{\text {st }}$, Harshavardhan, Ashoka the great, Raja Bhoj, Peshwa chiefs, Rani Kamlawati and the Nawabs of Bhopal dynasty. Sehore remained the head quarters of the political agent and resident of the British.

\section{List of Sample Self Help Group's:}

\begin{tabular}{|l|l|l|l|}
\hline S. No. & Block & Name of the SHG & Name of the Village \\
\hline 1. & Nasrullahganj & Radha & Hamidganj \\
\hline 2. & Narsullahganj & Shriram & ItawaKhurd \\
\hline 3. & Nasrullahganj & Vivekanand & BorkhedaKhurd \\
\hline 4. & Nasrullahganj & Mamta & Pipaliya \\
\hline 5. & Narsullahganj & Jyoti & Bhopalpur \\
\hline 6. & Sehore & Rajiv & Gudbhela \\
\hline 7. & Sehore & Laxmi & Bijori \\
\hline 8. & Sehore & Asha & Khunakalan \\
\hline 9. & Sehore & Chetna & Hirapur \\
\hline 10. & Sehore & Sharda & Bilkishanj \\
\hline
\end{tabular}

Socio - economic profile of the respondents

In any sociological investigation, the discussion of the socio-economic background of the respondents in an essential undertaking, because it is often observed that an individual's background has an important bearing on the formation of an individual's attitude, belief, commitment to his work and in making up of his entire personality. His family, caste, school, neighborhood, level of education, type of occupation \& income derived there from, all determine to a great extent the type and quality of his attitudes and values. Similarly, the social class from which they come from has a very significant impact on motivation for work which in turn determines their status. The attitude and values of an individual also affect their role performance \& adjustment pattern.

Women in India represent a more traditional section of society and have been reflected throughout the ages. Therefore, their participation in any walk of life is viewed as a sign of progress, particularly in the case of economic field. In this context, it is necessary to know from what strata of society they are drawn. It gives us and insight into the social processes of a traditional society. One of the methods of analyzing this is to examine the socio-economic background.

The level of socio-economic condition of women indicates their level of status in any society. It is heterogeneous, complex and highly stratified society like ours; the position and status of women naturally differ from one region to another region, one class to another class, from one religion to another religion, from one caste to another caste \& from one occupation to another. Significantly, large number of research studies in the social and behavioural sciences like sociology, education, psychology frequently use socio-economic status as one of the Independent variables. Several studies conclusively 
demonstrated that socio-economic factors bear an important relation to experimental out course.

Age, education, caste, religion, marital status, family income, housing conditions etc. are some of the important variables that affect women in their empowerment and development. In this part of the study, an attempt has been made to analyze the socioeconomic profile of the respondents in the study area. Including three in the analysis of age structure of the respondents, social category, religion marital status, type of family, family size, livelihood sources; apart from this, education, income, husband's education, annual household income, livelihood sources of the household, land holding status, facilities in the household, asset holding pattern of the household have also been dealt with.

\section{Age structure}

Age is the key variable in understanding the socio economic status of an individual. It is one of the important variables in understanding women's status in society. With change in age, women's status \& role also changes. The young and middle age group people can actively participate in the socio-economic activities, which is true in the activities of SHGs in the study area

Table 4.1: Age structure of the Respondents

\begin{tabular}{|l|l|l|}
\hline Age & Number of Respondents & Percentage \\
\hline Below 25 years & 10 & $10 \%$ \\
\hline $25-35$ years & 40 & $40 \%$ \\
\hline $36-45$ years & 35 & $35 \%$ \\
\hline Above 45years & 15 & $15 \%$ \\
\hline Total & $\mathbf{1 0 0}$ & $\mathbf{1 0 0 \%}$ \\
\hline
\end{tabular}

The above table indicates that $40 \%$ of the total belongs to the age group of 25-35 yrs followed by $35 \%$ in the age group of $36-45$ yrs $10 \%$ of respondent's falls under the age group of $25 \mathrm{yrs} \& 15 \%$ are more than $45 \mathrm{yrs}$ of age. These suggest that most of the SHG numbers are in productive age group. This can lead higher impacts on the target households.

\section{Social category}

Since SHG is conceptually targeted of weaker sections, it would be interesting to look at the social status of the selected members. In general SC/ST families constitute the most vulnerable \& economically the most backward among the different communities. The project envisages covering the members of social \& economically weaker sections particularly community like SC/ST \& Backward classes.

Table 4.2: Social category

\begin{tabular}{|l|l|l|}
\hline Category & No. of Respondents & Percentage \\
\hline SC & 50 & $50 \%$ \\
\hline ST & 30 & $30 \%$ \\
\hline OBC & 15 & $15 \%$ \\
\hline General & 5 & $5 \%$ \\
\hline Total & $\mathbf{1 0 0}$ & $\mathbf{1 0 0 \%}$ \\
\hline
\end{tabular}

The distribution of respondents according to social category reveals that $50 \%$ of the respondents belong to schedule castes $30 \%$ of them belong to schedule tribes followed by backward classes at $15 \%$. Among the total sample, only $5 \%$ belong to the general category.

Table 4.3: Religion of the respondents

\begin{tabular}{|l|l|l|}
\hline Religion & No. of Respondents & Percentage \\
\hline Hinduism & 85 & $85 \%$ \\
\hline Christianity & 03 & $03 \%$ \\
\hline Islam & 12 & $12 \%$ \\
\hline Total & $\mathbf{1 0 0}$ & $\mathbf{1 0 0 \%}$ \\
\hline
\end{tabular}

The above table shows that in the present study $85 \%$ of the respondents belong to Hinduism, $12 \%$ respondents belong to Islam \& $3 \%$ of respondents belong to Christianity. 
Table 4.4: Marital status of the respondents

\begin{tabular}{|l|l|l|}
\hline Married status & No. of Respondents & Percentage \\
\hline Married & 85 & $85 \%$ \\
\hline Unmarried & 5 & $5 \%$ \\
\hline Widow/Separate & 10 & $10 \%$ \\
\hline Total & $\mathbf{1 0 0}$ & $\mathbf{1 0 0 \%}$ \\
\hline
\end{tabular}

The above table indicates that majority (85\%) of the respondents are married \& $10 \%$ are either widows or separated women \& only $5 \%$ of women's constitute single ones. From the above table we remember that a great majority of the members of SHGs are responsible housewives.

Table 4.5: Classification of Respondents by literacy level

\begin{tabular}{|l|l|l|}
\hline Education level & No. of Respondents & Percentage \\
\hline Illiterate & 50 & $50 \%$ \\
\hline Functionally literate & 20 & $20 \%$ \\
\hline Primary & 14 & $14 \%$ \\
\hline High School & 10 & $10 \%$ \\
\hline Higher Sec. School & 6 & $6 \%$ \\
\hline Total & $\mathbf{1 0 0}$ & $\mathbf{1 0 0 \%}$ \\
\hline
\end{tabular}

Education to women is the most powerful instrument to change their position in society. From the above table the educational status of the respondents shows that $50 \%$ of them are illiterate, $20 \%$ of the respondents are only functionally literates, $14 \%$ of the respondents have studied up to primary level \& $10 \%$ of the respondents are up to High school level \& only $6 \%$ are up to $\mathrm{Hr}$. Sec. Level. Joining SHGs, they also realized the importance of education, which resulted in increased number of members being able to sign.

Table 4.6: Type of Family

\begin{tabular}{|l|l|l|}
\hline Type & No. of Respondents & Percentage \\
\hline Nuclear & 60 & $60 \%$ \\
\hline Joint & 40 & $40 \%$ \\
\hline Total & $\mathbf{1 0 0}$ & $\mathbf{1 0 0 \%}$ \\
\hline
\end{tabular}

From the above table we see that $60 \%$ of the respondents are living in Nuclear families \& $40 \%$ of the respondents are living in joint families. Though, the custom of living in joint families is less as compared to nuclear families in rural areas.

Table 4.7: Family size of the Respondents

\begin{tabular}{|l|l|l|}
\hline No. of Family Members & No. of Respondents & Percentage \\
\hline Up to 4 & 19 & $19 \%$ \\
\hline $5-6$ & 55 & $55 \%$ \\
\hline More than 6 & 26 & $26 \%$ \\
\hline Total & $\mathbf{1 0 0}$ & $\mathbf{1 0 0 \%}$ \\
\hline
\end{tabular}

From this table it shows that $55 \%$ of the sample house holders had family size ranging between 5-6 members \& 19\% reported a family size of up to 4 members. Households with larges sized families more than 6 members constitute $26 \%$ of the total sample.

Table 4.8: Is the family women Headed?

\begin{tabular}{|l|l|l|}
\hline Response & No. of Respondents & Percentage \\
\hline Yes & 10 & $10 \%$ \\
\hline No & 90 & $90 \%$ \\
\hline Total & $\mathbf{1 0 0}$ & $\mathbf{1 0 0 \%}$ \\
\hline
\end{tabular}

The above table shows that about $10 \%$ the households are women leaded. This $10 \%$ comprises of mostly widows and separated women's.

Table 4.9: Livelihood source of respondents

\begin{tabular}{|l|l|l|}
\hline Occupation & No. of Respondents & Percentage \\
\hline Cultivation & 35 & $35 \%$ \\
\hline Share cropping & 03 & $3 \%$ \\
\hline Agricultural labour & 30 & $30 \%$ \\
\hline Wage labours & 12 & $12 \%$ \\
\hline Agriculture allied activities & 20 & $20 \%$ \\
\hline Total & $\mathbf{1 0 0}$ & $\mathbf{1 0 0 \%}$ \\
\hline
\end{tabular}


The above table shows that more women derive income from agricultural activities. Cultivation was found to be the main occupation of the respondents followed by agricultural labour and wage labour.

Table 4.10: Annual income of the respondents

\begin{tabular}{|l|l|l|}
\hline Income Range & No. of Respondents & Percentage \\
\hline Less than 5000 & 25 & $25 \%$ \\
\hline $5000-7000$ & 40 & $40 \%$ \\
\hline Above 7000 & 35 & $35 \%$ \\
\hline Total & $\mathbf{1 0 0}$ & $\mathbf{1 0 0 \%}$ \\
\hline
\end{tabular}

The above table indicate that $25 \%$ of the respondents were earning less than Rs. 5000 annually $40 \%$ had an income in the range of Rs. 5000-7000, 35\% having an income up to Rs. 7000 annually.

Table 4.11: Educational qualification of Husband

\begin{tabular}{|l|l|l|}
\hline Education qualification & No. of Respondents & Percentage \\
\hline Illiterate & 50 & $50 \%$ \\
\hline Functionally literate & 25 & $25 \%$ \\
\hline Primary & 10 & $10 \%$ \\
\hline Middle & 07 & $7 \%$ \\
\hline High School & 05 & $5 \%$ \\
\hline Hr. Secondary & 03 & $3 \%$ \\
\hline Total & $\mathbf{1 0 0}$ & $\mathbf{1 0 0 \%}$ \\
\hline
\end{tabular}

The educational qualification level of husbands of the respondents is very poor. $50 \%$ of respondents reported that their husbands are illiterate. This means that the education system in rural areas is very weak so Govt. should provide elementary/formal education in rural areas should be of prime focus.

Table 4.12: Livelihood sources of the Households

\begin{tabular}{|l|l|l|}
\hline Occupation & No. of Respondents & Percentage \\
\hline Cultivation & 40 & $40 \%$ \\
\hline Share cropping & 05 & $5 \%$ \\
\hline Agricultural labour & 35 & $35 \%$ \\
\hline Wage labours & 08 & $8 \%$ \\
\hline Agriculture allied activities & 12 & $12 \%$ \\
\hline Total & $\mathbf{1 0 0}$ & $\mathbf{1 0 0 \%}$ \\
\hline
\end{tabular}

From the above table we know that $40 \%$ of the household are dependent on cultivation. This means that agricultural activities were found to be the main occupation for their lively hood sources.

Table 4.13: Annual income of the respondents

\begin{tabular}{|l|l|l|}
\hline Income & No. of Respondents & Percentage \\
\hline Less than 10000 & 32 & $32 \%$ \\
\hline Rs 10000-15000 & 28 & $28 \%$ \\
\hline Rs 15000-20000 & 25 & $25 \%$ \\
\hline Above 20000 & 15 & $15 \%$ \\
\hline Total & $\mathbf{1 0 0}$ & $\mathbf{1 0 0 \%}$ \\
\hline
\end{tabular}

The above table indicates that $32 \%$ of the household were earning less than Rs. 10000 annually, $28 \%$ had an income in the range of $10,000-15000,25 \%$ had an income range of $15000-20000$ and $15 \%$ had an income above 20,000 annual.

Table 4.14: Access to drinking water (within premises)

\begin{tabular}{|l|l|l|l|l|}
\hline \multirow{2}{*}{ Response } & Pre - SHG & \multicolumn{3}{|l|}{ Post - SHG } \\
\cline { 2 - 5 } & No. & No. & \% \\
\hline Yes & 15 & $15 \%$ & 20 & $20 \%$ \\
\hline No & 85 & $85 \%$ & 80 & $80 \%$ \\
\hline Total & $\mathbf{1 0 0}$ & $\mathbf{1 0 0 \%}$ & $\mathbf{1 0 0}$ & $\mathbf{1 0 0 \%}$ \\
\hline
\end{tabular}

The above table shows that only $20 \%$ households stated to have access to drinking water within premises compared to $15 \%$ during pre-SHG situation. It shows that there has not been any significant change in the status with regard to drinking water. 
Table 4.15: Availability of sanitary toilet facility

\begin{tabular}{|l|l|l|l|l|}
\hline \multirow{2}{*}{ Response } & Pre - SHG & \multicolumn{2}{l|}{ Post - SHG } \\
\cline { 2 - 5 } & No. & \% & No. & \% \\
\hline Yes & 10 & $10 \%$ & 20 & $20 \%$ \\
\hline No & 90 & $90 \%$ & 80 & $80 \%$ \\
\hline Total & $\mathbf{1 0 0}$ & $\mathbf{1 0 0} \%$ & $\mathbf{1 0 0}$ & $\mathbf{1 0 0 \%}$ \\
\hline
\end{tabular}

According to this table, increased number of sanitary toilet facilities was noticed among the sample households. The availability has increased from $10 \%$ to $20 \%$ households

Table 4.16: Availability of Electricity facility

\begin{tabular}{|l|l|l|l|l|}
\hline \multirow{2}{*}{ Response } & Pre - SHG & \multicolumn{2}{l|}{ Post - SHG } \\
\cline { 2 - 5 } & No. & \% & No. & \% \\
\hline Yes & 90 & $90 \%$ & 96 & $96 \%$ \\
\hline No & 10 & $10 \%$ & 04 & $4 \%$ \\
\hline Total & $\mathbf{1 0 0}$ & $\mathbf{1 0 0 \%}$ & $\mathbf{1 0 0}$ & $\mathbf{1 0 0 \%}$ \\
\hline
\end{tabular}

In this table $96 \%$ of sample household reported the availability of electricity facility. This shows the general improvement in basic infrastructure is benefiting rural area.

Table 4.17: Fuel used for cooking

\begin{tabular}{|l|l|l|}
\hline Fuel & No. of Respondents & Percentage \\
\hline Dung cake & 40 & $40 \%$ \\
\hline Firewood & 45 & $45 \%$ \\
\hline LPG & 10 & $10 \%$ \\
\hline Kerosene & 5 & $5 \%$ \\
\hline Total & $\mathbf{1 0 0}$ & $\mathbf{1 0 0 \%}$ \\
\hline
\end{tabular}

The above table shows that fire wood is the most common type of fuel used for cooking i.e. $45 \%$ followed by cow dung cake $40 \%$. To some extent lesser householder used kerosene as fuel as compared to LPG.

The overall socio-economic profile of the women beneficiaries shows that women are mainly from lower segment of the society. They belong to middle age group and majority of them are low educated. Their family income is found to be low and they are mainly dependent on primary sector for livelihood with the easy access to micro-credit, women beneficiaries have availed the opportunities for self employment and other income generating activities.

\section{Summary and Conclusions:}

Rural women play a significant role in the domestic and socio-economic life of the society. Socio-economic empowerment has been considered instrumental for holistic development. Women's empowerment is obviously essential for raising their socioeconomic status in the society. Recently women's empowerment has acquired an important place in government policy, nongovernmental advocacy \& academic research.

However, more than $90 \%$ of the rural women are unskilled, restricting them to low paid occupations. Women have little control over land and other productive assets which excludes them from access to institution credit. Micro finance interventions are wellrecognized world over as an effective tool for poverty alleviation \& improving socioeconomic status of the rural poor. In India also, micro finance is making headway in its effort for reducing poverty and empowering rural women.

Self help groups play an important role in the socio-economic empowerment of women and in income generating activities. The present study attempts to determine whether and to what extent SHGs has an impact on the overall empowerment of rural women in the sehore district of Madhya Pradesh. An attempt has been made in this chapter to incorporate the summaries, conclusions \& suggestions that have been arrived at in the course of this study.

\section{Socio - Economic profile of respondents:}

Socio-economic profile of the respondents reveals that the young and middle age group can actively participate in the socio-economic activities as more than 75 percent the respondents belonged to the age group of 26-45 years. Self help group protects conceptually targeted to socially and economically weaker sections. The composition of groups shows that most of the members belonged to SC, ST, \& OBC (95\%). The Hindus 
are in large quantity. 85 percent of the respondents belonged to Hinduism followed by Islam $(12 \%) \&$ Christianity (3\%). About 85 percent of the respondents were married \& 10 percent were either widows or separated.

The study reveals that majority of the respondents and their husbands were either illiterate or educationally backward. Only 10 percent of the respondents reported to have educational status of high school \& above. 60 percent of the respondents were living in nuclear families. Majority of them had a family size ranging from 4 to 6 members. This was due to the joint family system still found in the study area. It was also found that only 10 percent of the total families of the respondents were women headed mostly comprised of widow and separated women. Cultivation was found to be the main occupation of the respondents as well as their households followed by agricultural labour and wage labour. The finding of this study indicates that about 65 percent of the respondents had an annual income less than 7000; only 35 percent respondent's reported annual income above Rs. 7000. The number of respondents with annual family income less than Rs. 10000 formed 32 percent of the total, where as 53 percent reported annual family income between Rs. 10,000 to 20,000. This indicates that SHG project helps in increasing the needs of the poor. However, the income of respondents as well as their households has increased after project intervention. The analysis of the facilities in the respondent's households reveals that only 20 percent respondents had access to drinking water within premises and 20 percent reported availability of sanitary toilet facility. Majority of the respondents had electricity facility in their houses $(96 \%)$. Dung cake \& fire wood was the most common type of fuel used for cooking by the households.

The study reveals that the implementation of SHG projects has provided respondents with lots of skills which have improved the income of the respondents as well as their households. Also they realize the importance of education which resulted in increased number of members being able to sign.

\section{Constitution and functioning of SHGs:}

All the respondents had been member of the SHGs for more than five years. The size of the group plays an important role in process of group dynamics. The majority of the groups reported to be comprising of 11-15 members. NGO facilitators were the leading source of information for most of the respondents followed by SHG and family members. Although 25 percent of the respondents joined SHGs by self motivation, majority of the NGO facilitators, husband \& family members were the motivating agents. Those who were already members in SHGs also become motivating agents.

It is significant to note that 40 percent of the respondents having the motivating factor for jointing the SHG are to save habit and getting easy loan at a reduced rate of interest. However, the social motives like increase in social status, interaction with other women in their area, gaining knowledge, skills \& a desire to work for the development of community, influenced, 12 percent of the respondents.

The findings of the study reveals that 80 percent of the respondents were ordinary members of SHGs, while 10 percent were secretaries \& another 10 percent were presidents of the SHGs.

Most of the SHGs conducted monthly meetings (65\%) followed by fortnightly $(20 \%)$ and weekly meetings (15\%). About 37 percent of groups were conducting meetings at the residence of the president or secretary of the group while as 43 percent of SHGs were conducting meetings in common places like panchayat office, Anganwadi residence, village community hall etc. About 20 percent of groups had no specific place to conduct meeting. 60 percent of the respondents have attendance more than $90 \%$ percent and only 30 percent have attendance between $70-90 \%$. The higher percentage of attendance was found due to imposing fine for late attendance or absence in the meetings.

The study also reveals that the meetings were mostly organized by office bearers in consultation with group members followed by NGO facilitators and SHG members. Majority of the members decided the agenda of the meetings. The decisions in group meetings were taken by consensus $(55 \%)$ followed by voting $(23 \%)$ and by office bearers and NGO facilitators $(22 \%)$. It is significant to note that confidence of respondents in holding group meetings had considerable increased. Majority of them are able to hold meetings in the absence of NGO facilitators. 
The sample SHGs saved from a lowest of Rs. 10 to Rs. 50 per member per month. Majority of sample SHGs (55\%) saved Rs. 21 to 30 per member per month followed by 31 percent saving Rs. 11 to 20 per member per month. The frequency of group savings for majority of respondents $(65 \%)$ was monthly followed by fortnightly and weekly. About 45 percent of the SHG members reported increase in savings rate over a period of time. Increase in savings is directly related to improvement in economic status of life. This leads to the acceptance of hypothesis that poor women are capable of thrift and sowings.

The findings of the study reveal that 79 Percent of the respondents have availed loan from group fund. So, generally the members have moved from small, short consumption loans to bigger term production loans. This means there is increase in production loans and reduction in consumption loans currently most of loans are being taken for agricultural activity, animal husbandry marriages, medical expenditure etc. The repayment performance of members to SHGs had been reported at 95 percent. This means that they are able to earning during off seasons \& are able to repay loans. This leads to the acceptance of hypothesis that among the real and potential clients or microfinance, women are seen as the most reliable in terms of repayment and utilization of loans. About 80 percent of the respondent said that documents were maintained properly while 15 percent of the respondents say that there was no proper maintenance of group records.

The study further reveals that only 35 percent of the sample SHGs followed the practice of rotation of leadership where as 65 percent did not adopt this practice. A trend seemed to have emerged and the better offer leaders dominating the groups \& getting reelected again and again due to the following reasons:

- Illiteracy, absence of numerical skills \& educational backwardness of the members.

- Lack of ability to take part in group activity.

- Interest shown by leaders for continuing in their leadership positions.

The study also reveals that after joining the self help group, 60 percent of women members are taking benefits from other govt. schemes for their personal benefit such as pension scheme, Indira Aavass Yojena, etc. This shows that after joining SHG, these women members are trying to work hard for their overall development. After joining SHGs, the members have also increased knowledge about health and hygiene. I.e. they are now aware about vaccinating children's, causes of diarrhea, nutritional care of pregnant women's, washing hands before eating./cooking, family planning, child education etc.

So, the study overall shows increase in socio economic conditions of these poor women and also an increase in awareness. This increase in knowledge is only due to the involvement of these women with the SHGs. The study also reported an increase in workload \& responsibilities after joining SHGs. They are happy with this workload because they are getting more benefits.

\section{Suggestions}

Considering the findings of the study, the following suggestions are prescribed.

- Women empowerment should be reflected through a direct budgetary commitment rather than a core component of all development agenda. The micro credit as a component should reflect in the policies and plans oriented towards women's empowerment to enhance women's agency on social political \& economic levels. Women's agency must be given primacy. Women's rights over property rights need to be enhanced and decision making needs to be ensured in all programme components.

- About 20 percent of groups had no place to conduct meetings. They conducted meeting either on the village roads or under the village trees etc. These calls for strengthening village infrastructure in terms of providing at least one room community halls were these groups can meet \& transact their business.

- Only 35 percent of the sample SHGs reported following the practice of rotation or election of leaders. Low leadership rotation may lead to major difficulties \& causation of moral hazards. Therefore, it has to be ensured that leadership rotation or election of leaders is strictly to be practiced for future sustainability of the group. Change of leader is must for sharing the responsibilities by all members.

- The office bearers managing the group should be given financial benefits which will enable them to be more involved in the activities of the group. 
- The rate of illiteracy can be further reduced through the existing programmes. Formal education will focus on critical issues needed for functional literacy should be imparted to the women groups so that they can manage their group affairs independently.

- In several cases, banker shows less attitude in promoting SHGs. Occasionally, they point reasons like shortage of staff; time etc. just to avoid dealing with SHG promotion. Training for capacity building and to change their attitude should be thrust upon bankers for strengthening SHGs promoted by bankers.

- NGOs are linked in one way for SHGs. NGOs on an experimental basis should attempt gradual withdrawal and see whether the groups are able to function and transact their day to day operations independently.

- The study observed that few groups have utilized their services for various development works in their village. Efforts should be directed for the SHGs because these SHGs of the villages may be associated effectively in all developmental works such as infrastructure development, construction of schools, roads, buildings, hospitals etc.

- Marketing of new distribution may involve training or community development skills. There is need to evolve training package for entrepreneurship development to enable women as successful business managers. In this task NGOs, Panchayats, may be enhanced to impart training skill development \& technical knowledge.

- The overlapping of programmes in the same block creates confusion and therefore, this should be discouraged while as the provision of revolving funds for the SHGs may be ensured.

Thus projects need to invest in mobilization participation, leadership training and education. This will not only maximize income opportunities for women but more importantly, enhance women's potential to mobilize external strengths to bring about fundamental changes.

\section{References:}

[1]. Anand, Jaya, Self help groups in Empowering women: case study of selected SHGs, discussion paper No. $38,(2002)$

[2]. Bagati, Deepali. "Micro credit \& Empowerment of women." Manuscript. Article based on doctoral dissertation research at Brynmawr college, PA (2001)

[3]. Batliwala, Srilatha, Education for women's empowerment, ASPBAE position paper for the fourth world conference on women, Beijing, September 1995, New Delhi, Asia South Pacific Bureau of Adult Education (1995).

[4]. Cheston, Susy, Lisa, Empowering women through Micro Finance, Washington DC, USA: Micro Credit summit campaign, (2002).

[5]. Deshpanda, Rani; Increasing Access and Benefits for women: Practices and Innovations among microfinance institutions - survey results. New York: UNCDF, (2001).

[6]. ESCAP. Social safety nets for women. United Nations publication (2002).

[7]. Fernandez, AP, The MYRADE Experience; alternative management system for savings and credit of the rural poor, Mysore resettlement and development agency Bangalore, (1998).

[8]. Government of India, National policy for the empowerment of women, New Delhi, department of women and child development, Ministry of human resource development (2001).

[9]. Gurumoorthy, T.R; Self help groups empower rural women, kurukshetrafeb, (2000).

[10]. Government of India, on wings of change taking women upward: An Indian experiment, New Delhi, swashakti Project, Government of India, (2005).

[11]. Naggayya, D; Micro finance for self help groups, Kurukshetra, August, (2000).

[12]. NABARD, NABARD and Micro finance, National bank for agriculture and rural development, Mumbai, (1999-2000)

[13]. Mayouxl. 2000. Micro finance \& the empowerment of women: a review of the key issues. Social finance unit working paper, 23, ILO, Geneva.

[14]. Meenai, Zubair, Empowering rural women: An Approach to empowering women through credit based, Self Help groups, Delhi (2003).

[15]. NABARD. SHG Bank Linkage in India. Mumbai, NABARD, (2003).

[16]. Puhazhendhi, V, Evolution study of self help groups in Tamil Nadu, National Bank for Agriculture and Rural Development, Mumbai (2000).

[17]. Satish, P, Some issues in the information of self help groups, Indian journal of agricultural economics, vol. 56 , No. 3, July- September, Mumbai, (2000).

[18]. Shrestha, Milan. Report on Self Help banking program and women's empowerment. Nepal, 1998.

[19]. Singh, S.K. \&Pandey, S.P; Empowerment of schedule caste women through self help groups, serials publications, New Delhi, 2007.

[20]. Zafar, Rohshaneh, "Microfinance and the empowerment of women; the experience of kashf foundation, Pakistan." presented at the microcredit summit, meeting of councils, New Delhi $1-5,2001$. 